\title{
Wheat Lodging and Yield in Response to Cultivars and Foliar Application of Paclobutrazol
}

\author{
Zenhom, M. F. T; G. Y. Hammam and S. A. S. Mehasen* \\ ${ }^{1}$ Dept. of Agron., Fac. of Agric., Moshtohor, Benha Univ., Egypt. \\ *Corresponding author: S.A.S. Mehasen, Head Department of Agronomy, Faculty of Agriculture at \\ moshtohor, Benha University, Egypt. PO Box 13736
}

Corresponding authors: mehasensas92@yahoo.com

\begin{abstract}
Two field experiments were conducted at the Research and Experimental Center of Faculty of Agriculture at Moshtohor, Benha University, Egypt, during 2015/16 and 2016/17 winter seasons to evaluate five wheat cultivars includes Misr 2, Gemmeza 11, Shandaweel 1, Giza 171 and Sids 12 under three foliar application of Paclobutrazol \{plant growth retardant (PGR)\} at rates 0, 100, $200 \mathrm{ppm} \mathrm{fad}^{-1}$ for root lodging, yield and yield components. The obtained results for combined analyses were as follows:

The significant effect of PGR observed for root dry weight plant ${ }^{-1}$, plant height, No. of tillers $\mathrm{m}^{-2}$, No. of spikes $\mathrm{m}^{-2}$, No. of kernels spike ${ }^{-1}$ and straw yield fed ${ }^{-1}$. Cultivars were varied significantly in lodging score, root dry weight plant ${ }^{-1}$, plant height, No. of tillers $\mathrm{m}^{-2}$, No. of spikes $\mathrm{m}^{-2}$, seed index, grain yield fed ${ }^{-1}$, straw yield fed ${ }^{1}$ and harvest index. While PGR $\times$ cultivars interactions showed no significance effect on all these traits.
\end{abstract}

Key Words: Spring wheat, Foliar application of Paclobutrazol, Cultivars, Yield and its components.

\section{Introduction}

Spring wheat (Triticum aestivum L.) is represented the first strategic crop in Egypt and is considered the main source of food in the world and Egypt. Raising wheat production through increasing productivity and increasing the cultivated area is an important national target to minimize the gap between the Egyptian production and consumption. Increasing wheat yield per unit area can be achieved by breeding high yielding varieties and improving the cultural treatments of the crop. root lodging is considered as a crucial factor which could induce massive reduction in yield. Root lodging is defined as the permanent displacement of plant stems from their vertical position as a result of wind acting on the shoot and rain or irrigation weakening the soil and reducing anchorage strength. Plant growth regulators (PGRs) comprise a large group of endogenous and exogenous chemical compounds that can regulate plant growth in numerous ways. High seeding rates are used in spring cereals to promote main shoot dominance in plant stands and in yield formation in Finnish growing conditions. Therefore, PGR induced effects and the potential to manipulate cereal growth and yield formation may differ markedly according to growing conditions, especially daylength and management practices. It is common agronomic practice to treat cereal crops with plant growth regulators (PGRs), to control lodging. Ethephon (2chloroethylphosphonic acid), which breaks down in the plant to release ethene, and Chlormequat, which inhibits gibberellin synthesis by blocking the cyclization of geranylgeranyl pyrophosphate, both restrict stem internode elongation and can increase yield, particularly under severe lodging conditions (Nafziger et al, 1986; Webster and Jackson, 1993). PGRs have been and are still mainly used in modern, high input cereal management to shorten stems and thereby to increase lodging resistance (Rajala and Peltonen-Sainio, 2001). Sinniah et al (2012) sown rice in a greenhouse with seeding rate equivalent to $25 \mathrm{~kg} \mathrm{fad}^{-1}$ and sprayed plants by Paclobutrazol at 0 , 50, 100 and $200 \mathrm{ppm}$ during panicle initiation. They found that lodging resistance of treated plants at either 50 or 100 or 200 was found to be significantly higher than untreated plants by averaged $27.3 \%$ due to the reduction in culm length and treated rice plants by Paclobutrazole at either 50 or 100 or 200 ppm had the same effect on the number of grains per panicle but these dosages increased grains panicle ${ }^{-1}$ significantly by averaged $4.7 \%$ when compared with untreated plants. Shekoofa and Emam (2008) showed also that both of CCC and Ethephon increased number of tillers and spikes per square meter significantly by at least $6.3 \%$ when compared with untreated plants. Pinera-Chavez et al (2016) reported that lodging risk increases when the soil surface is wet, typically when the first $50 \mathrm{~mm}$ of soil is at field capacity.

Several investigators showed that wheat cultivars differed in growth, yield and its components (Mehasen,1999; Abd El-Hameed, 2002; Ali et al, 2004; Tripathi et al, 2004; Mehasen and Mohamed, 2005; Abu-Grab et al, 2006; Omar, 2007; Ramadan and Awaad (2008); Mehasen et al, 2009; Ashmawy et al, 2010; Abd El-Nour and Fateh,2011; Mehasen et al, 2013, Mehasen et al, 2014; Mehasen et al, 2015 and Pinera-Chavez et al, 2016).

The subject of this work is the evaluation of five wheat cultivars under three foliar application of Paclobutrazol for root lodging, yield and yield components in Kalubia Governorate. 


\section{Materials and Methods}

The present study was carried out at the Agricultural Experiments and Researches Center, Faculty of Agriculture Moshtohor, Benha University, Egypt through the two successive growing winter seasons of $2015 / 16$ and $2016 / 17$ to evaluate five wheat cultivars includes Misr 2, Gemmeza 11, Shandaweel 1, Giza 171 and Sids 12 under three foliar application of Paclobutrazol \{plant growth retardant (PGR) $\}$ at rates $0,100,200 \mathrm{ppm} \mathrm{fad}^{-1}$ for root lodging, yield and yield components. The soil was clay in texture, $\mathrm{pH}$ values, organic matter content and available $\mathrm{N}$ were $7.81,1.69$ and $45 \mathrm{ppm}$ means in the two growing seasons. The treatments were assigned in a split-plot design with three replications. PGR rates were arranged at random in the main plots while, five wheat cultivars occupied the sub-plots. The sub-plot area was $10.5 \mathrm{~m}^{2}$. Wheat grains were cultivated on November $29^{\text {th }}$ in both seasons. P fertilizer with the rate of $15.5 \mathrm{~kg} \mathrm{P}_{2} \mathrm{O}_{5}$ fed $^{-1}$ was one equal dose as calcium super phosphate form (15.5\% $\left.\mathrm{P}_{2} \mathrm{O}_{5}\right)$ applied before sowing during seedbed preparation. At the beginning of the tillering stage main plots were sprayed with paclobutrazole at 0,50 and $100 \mathrm{ppm} \mathrm{fad}^{-1}$, and then repeated at the beginning of stem elongation, thus plots were received totally 0 , 100 and $200 \mathrm{ppm} \mathrm{fad}^{-1}$. N fertilizer recommended rate was splitted into three equal doses as urea form $(46 \% \mathrm{~N})$ applied before the first, second and third irrigations in both season. The preceding crop was maize in both seasons. The normal cultural practices were carried out as recommends.

\section{- Collected data.}

After the $4^{\text {th }}$ irrigation during anthesis stage, all susceptible plants were lodged at wind speed of $8 \mathrm{~m} / \mathrm{s}$ with very little amounts of precipitation (0.1 $\mathrm{mm} / \mathrm{month}$ ) during March in both successive seasons. Total coronal roots included the ten separated roots were oven dried at $75^{\circ} \mathrm{C}$ for 48 hours as described by (Traipathi et al, 2004) to measure the root dry weight plant $^{-1}(\mathrm{~g})$. At ripening, ten plants were sampled from each plot to determine plant height $(\mathrm{cm})$, kernels spike ${ }^{-1}$ and seed index. Plants in three adjacent rows from the central of each plot were sampled to determine number of tillers and spikes $\mathrm{m}^{-}$ ${ }^{2}$. Grain and straw yields $\mathrm{kg} \mathrm{fed}^{-1}$ were estimated on $1.4 \mathrm{~m}^{2}$ taken sub-plot. Harvest index (HI) was calculated by using the formula:

$\mathrm{HI}=$ Grain yield $\mathrm{kg} \mathrm{fed}^{-1} /$ Biological yield $\mathrm{kg} \mathrm{fed}^{-1}$

$$
\times 100
$$

\section{- Statistical analysis.}

Data were combined across two seasons and statistically analyzed by SPSS program (version, 23) using GLM UNIVARIATE procedure. The least significant difference (LSD) test was used when mean difference were significant at the $\mathrm{P}<0.05$ level. Simple analysis was determined for combined data across 2015 and 2016 seasons between lodging score as a dependent variable with other plant characters where each of them was considered as an independent variable.

\section{Results and Discussion}

Analysis of variances for all traits in each season as well as the combined analysis is presented in Table (1). Test of homogeneity revealed that the error variance for the two seasons were homogenous, therefore combined analysis was processed. Year's mean squares were not significant for all the studied traits. PGR rates mean squares were highly significant for root dry weight and was significant only for plant height, No. of tillers $\mathrm{m}^{-2}$, No. of spikes $\mathrm{m}^{-2}$, No. of kernels spike ${ }^{-1}$ and straw yield fed ${ }^{-1}$ in the combined data. Wheat cultivars mean squares were highly significant for lodging score, root dry weight plant $^{-1}$, plant height, No. of tillers $\mathrm{m}^{-2}$, No. of spikes $\mathrm{m}^{-2}$, seed index, grain yield $\mathrm{fed}^{-1}$ and straw yield fed ${ }^{-1}$ and were significant only for harvest index in the combined data. The interaction between PGR rates and wheat cultivars mean squares was not significant for all of the studied characters in the combined data.

\section{- Plant growth retardant effect.}

Results in Table (1) indicated that, growth, yield and its attributes of wheat i.e. root dry weight plant ${ }^{-1}$, plant height, No. of tillers $\mathrm{m}^{-2}$, No. of spikes $\mathrm{m}^{-2}$, No. of kernels spike $^{-1}$ and straw yield fed $^{-1}$ were significantly affected by PGR rates in the combined analysis, while lodging score, seed index, grain yield fed $^{-1}$ and harvest index were not significantly affected by PGR rates in the combined analysis. It is clear that the significant highest values of root dry weight plant $^{-1}(0.390 \mathrm{~g})$, No. of tillers $\mathrm{m}^{-2}$ (617.20 tiller), No. of spikes $\mathrm{m}^{-2}$ (527.87 tiller) and straw yield $\mathrm{fed}^{-1}$ $(3703 \mathrm{~kg})$ were produced by PGR application at a rate $200 \mathrm{ppm}$ treatment compared with other treatments, whereas, it is clear that the significant highest values of plant height $(117.53 \mathrm{~cm})$ and No. of kernels spike ${ }^{-1}$ (31.63) were produced by the control treatment (zero PGR) compared with other treatments. On the other hand, the control treatment producing the lowest values of root dry weight plant ${ }^{-1}$ (0.296 g), No. of tillers $\mathrm{m}^{-2}$ (519.73 tiller), No. of spikes $\mathrm{m}^{-2}$ (434.00 tiller) and straw yield fed ${ }^{-1}$ (3304 $\mathrm{kg}$ ). Yet, favorable significant increases in root dry weight by PGR application still not enough to improve lodging resistance in susceptible cultivars, this might indicates whether there are other root traits strongly affected lodging behavior which did not affected positively by PGR application; or lodging behavior depending on all root traits collectively; and/or other morphological plant characteristics. The present results are in full harmony with those of Rajala and Peltonen-Sainio (2001); Alam et al (2002); Berry et al (2004); Ramburan and Greenfield (2007); Shekoofa and Emam (2008); Sinniah et al (2012) and Pinera-Chavez et al. (2016). 
Table 1. Growth, yield and yield components of wheat as affected by Paclobutrazol and cultivars as well as analysis of variance (Combined analysis of $2015 / 16$ and 2016/17 seasons)

\begin{tabular}{|c|c|c|c|c|c|c|c|c|c|c|}
\hline Treatments & $\begin{array}{c}\text { Lodging } \\
\text { score }\end{array}$ & $\begin{array}{c}\text { Root dry } \\
\text { weight } \\
\text { (g) }\end{array}$ & $\begin{array}{c}\text { Plant } \\
\text { height } \\
\text { (cm) }\end{array}$ & $\begin{array}{c}\text { No. of } \\
\text { tillers } \\
\mathrm{m}^{-2}\end{array}$ & $\begin{array}{c}\text { No. of } \\
\text { spikes } \\
\text { m }^{-2}\end{array}$ & $\begin{array}{c}\text { No. of } \\
\text { kernels } \\
\text { spike }^{-1}\end{array}$ & $\begin{array}{c}\text { Seed } \\
\text { index } \\
(\mathrm{g})\end{array}$ & $\begin{array}{c}\text { Grain } \\
\text { yield } \\
\left(\mathrm{kg} \mathrm{fed}^{-1}\right)\end{array}$ & $\begin{array}{c}\text { Straw } \\
\text { yield } \\
\left(\text { kg fed }^{-1}\right)\end{array}$ & $\begin{array}{c}\text { Harvest } \\
\text { index } \\
\%\end{array}$ \\
\hline \multicolumn{11}{|c|}{ Paclobutrazole (ppm) } \\
\hline zero & 27.55 & 0.296 & 117.53 & 519.73 & 434.00 & 31.63 & 37.78 & 2847.13 & 3304 & 46.29 \\
\hline 100 & 26.86 & 0.351 & 99.73 & 595.13 & 499.13 & 27.91 & 40.31 & 2996.67 & 3563 & 45.68 \\
\hline 200 & 26.39 & 0.390 & 89.60 & 617.20 & 527.87 & 27.61 & 45.55 & 3037.20 & 3703 & 45.06 \\
\hline L.S.D at $5 \%$ & NS & 0.019 & 13.74 & 70.85 & 71.75 & 4.01 & NS & NS & 213 & NS \\
\hline \multicolumn{11}{|l|}{ Cultivars } \\
\hline Misr 2 & 0.00 & 0.401 & 107.33 & 642.67 & 489.22 & 26.39 & 44.20 & 3169 & 3687 & 46.56 \\
\hline Gemmeza 11 & 0.00 & 0.427 & 108.00 & 677.89 & 499.44 & 28.39 & 44.00 & 3091 & 3987 & 43.89 \\
\hline Shandawel I & 0.00 & 0.367 & 106.89 & 610.33 & 493.00 & 29.44 & 43.67 & 2980 & 3650 & 46.54 \\
\hline Giza 171 & 64.36 & 0.270 & 86.67 & 484.56 & 483.33 & 27.32 & 37.10 & 2789 & 3498 & 44.73 \\
\hline Sids 12 & 70.29 & 0.264 & 102.56 & 471.33 & 470.00 & 27.23 & 37.10 & 2773 & 3392 & 45.75 \\
\hline L.S.D at $5 \%$ & 9.87 & 0.037 & 9.07 & 59.12 & NS & NS & 6.21 & 189 & NS & NS \\
\hline \multicolumn{11}{|c|}{ Source of variation } \\
\hline Replication & 80.515 & $0.003 *$ & 498 & 22689 & 6460.00 & 30.00 & 38.09 & 99536.42 & 59045.08 & 44.82 \\
\hline PGR & 5.106 & $0.034 * *$ & 2999* & 39180* & 34697.3* & 235.06* & 35.452 & 460128.19 & $6249356 *$ & 109.67 \\
\hline Error(a) & 106.746 & 0.000 & 184 & 4884 & 5009 & 15.7 & 64.8 & 57183 & 834242 & 38.1 \\
\hline Cultivar (C) & $12279 * *$ & $0.051 * *$ & $728 * *$ & $79453 * *$ & 1121.06 & 12.53 & $127.1 *$ & $6249356 * *$ & 460128.19 & 12.25 \\
\hline PGR $\times \mathbf{C}$ & 2.010 & 0.001 & 207 & 2051 & 1718.07 & 2.70 & 12.15 & 341255.54 & 341255.5 & 24.05 \\
\hline Error(b) & 102.968 & 0.001 & 86.9 & 3693 & 3599 & 8.2 & 40.7 & 43467 & 514701 & 24.7 \\
\hline
\end{tabular}

NS= not significant; *,**indicates significant at the $0.05,0.01$ levels, respectively 


\section{-Effect of cultivars}

The results reported in Table (1) indicate clearly that, there were significant differences between the different wheat cultivars in all studied traits except No. of spikes $\mathrm{m}^{-2}$, No. of kernels spike ${ }^{-1}$, straw yield $\mathrm{fed}^{-1}$ and harvest index in the combined analysis. Moreover; it is clear from Table (1) that Gemmeza 11 cultivar gave the highest values of root dry weight plant $^{-1}(0.427 \mathrm{~g})$, plant height $(108.00 \mathrm{~cm})$ and No. of tillers $\mathrm{m}^{-2}$ (677.89 tiller) whereas Misr 2 cultivar gave the highest values of seed index $(44.20 \mathrm{~g})$ and grain yield $\mathrm{fed}^{-1}(3169 \mathrm{~kg})$. On the other hand, Sids 12 cultivar gave the lowest values of root dry weight plant $^{-1}(0.264 \mathrm{~g})$, No. of tillers $\mathrm{m}^{-2}$ (471.33 tiller), No. of spikes $\mathrm{m}^{-2}$ (470.00 tiller), seed index (37.10 g), grain yield fed ${ }^{-1}(2773 \mathrm{~kg})$ and straw yield fed ${ }^{-1}(3392$ $\mathrm{kg}$ ), whereas Giza 171 cultivar gave the lowest values of plant height $(86.67 \mathrm{~cm})$ and harvest index $(36.31)$. It could be concluded that varietal differences among wheat cultivars may be due to genetical make up. The superiority of Gemmeiza 11 cultivar in grain yield $\left(\mathrm{kg} \mathrm{fed}^{-1}\right)$ over other wheat cultivars might be due to the increase in yield components, namely, spike length, No. of spikelets spike ${ }^{-1}$ and seed index. The results obtained by Mehasen (1999); Toaima et al (2000); Abd El-Hameed (2002); Ali et al (2004); Tripathi et al (2004); Mehasen and Mohamed (2005); Abu-Grab et al (2006); Omar (2007); Ramadan and Awaad (2008); Mehasen et al (2009); Ashmawy et al, (2010); Abd El-Nour and Fateh (2011); Mehasen et al, (2013), Mehasen et al, (2014); Mehasen et al (2015) and Pinera-Chavez et al. (2016) indicated marked differences among wheat varieties in growth, yield and yield components.

\section{-Interaction effect:}

Insignificant effect of interaction between PGR rates and wheat cultivars was obtained for all growth, yield and yield components namely, lodging score, root dry weight plant ${ }^{-1}$, plant height, No. of tillers $\mathrm{m}^{-}$ ${ }^{2}$, No. of spikes $\mathrm{m}^{-2}$, No. of kernels spike ${ }^{-1}$, seed index, grain yield fed ${ }^{-1}$, straw yield $\mathrm{fed}^{-1}$ and harvest index in the combined analysis (Table 1).

\section{References}

Abd El-Hameed, I. A. (2002): Effect of some agromomic practices on wheat. Ph. D. Thesis, Fac. Agric., Zagazig Univ., Egypt.

Abd El-Nour, Nadya, A. R. and Hayam S. A. Fateh (2011). Influence of sowing date and nitrogen fertilization on yield and its components in some bread wheat genotypes. Egypt. J .Agric. Res, 89(4):1413-1433.

Abu-Grab, O.S.; A. M. Mousa and G.A. ElShaarawy (2006): Photosynthetic and N-use efficiencies for some wheat cultivars in relation to planting density and nitrogen fertilization levels. Egypt. J. Appl. Sci., 21(2B): 475-492.

Alam, S. M., A. Shereen, and M. A. Khan. 2002. Growth response of wheat cultivars to
Naphthalene Acetic Acid (NAA) and Ethrel. Pak. J. Bot. 34(2):135-137.

Ali, G. A.; O. E. Zeiton; A. H. Bassiouny and A. R. Y. A. El-Banna (2004): Productivity of wheat cultivars grown at El-Khattara and El-Arish under different levels of planting densities and $\mathrm{N}$ fertilization. Zagazig J. Agric. Res., 31(4A): 1225-1256.

Ashmawy, F., M. S. El-Habal, H. S. Saoudy and ImanKh. Abbas (2010). The relative contribution of yield components to grain yield of some wheat cultivars grown under different nitrogen fertilizer levels. Egypt. J. Agric. Res., 88(1):225-239.

Berry, P. M., M. Sterling, J. H. Spink, C. J. Baker, R. Sylvester-Bradley, and S. J. Mooney. 2004. Understanding and reducing lodging in cereals. Adv. Agron. 84:217-271.

Mehasen, S. A. S and N. A. Mohamed (2005): multivariate and response curve analyses for yield and its attributes in some wheat cultivars under nitrogen fertilization levels. Egypt. J. Appl. Sci., 20(2): 93-109.

Mehasen, S. A. S. (1999): Response of some wheat varieties to agrispon foliar application and nitrogen rates. Annals of Agric. Sci., Moshtohor, 37(2): $853-864$.

Mehasen, S. A. S., El-Gizawy, N. Kh., Sharoba, A. M., Soliman, S. A. and Khalil, T. R. M. 2014. Yield and chemical composition of bread wheat cultivars as affected by some skipping irrigation. Minufiya J. Agric. Res. 39(3):1009-1018.

Mehasen, S. A. S., M. A. Ahmed and S. Sh. Abdullah (2013). Improving productivity of bread wheat genotypes by using of some growth promoters. Egypt. J. Plant Breed., 17(2):4-15.

Mehasen, S. A. S.; M. A. Ahmed and M. A. M. Morsy (2009): Evaluation of some wheat genotypes under different seeding rates. Annals of Agric. Sci., Moshtohor, 47 (3):167-174.

Mehasen, S.A.S.; Shimaa A. Badawy and S. Sh. Abdullah (2015). Influence of bio and mineral nitrogen fertilizers on productivity of some bread wheat varieties. J. of Food, Agriculture \& Environment Vol.13 (2): 162-167.

Nafziger ED, Wax L, Brown CM. 1986. Response of five winter wheat cultivars to growth regulators and increased nitrogen. Crop Science 26:767770 .

Omar, A. E. A. (2007): Productivity of some wheat cultivars as affected by sowing date and seeding rate. Egypt. J. Appl. Sci., 22(3): 103-116.

Pinera-Chavez, F. J., P. M. Berry, M. J. Foulkes, M. A. Jesson, and M. P. Renolds. 2016. Avoiding lodging in irrigated spring wheat. I. Stem and root structural requirements. Field Crops Res. 196:325-336.

Rajala, A., and P. Peltonen-Sainio. 2001. Plant growth regulator effects on spring cereal root and shoot growth. Agron. J. 93:936-943. 
Ramadan, A. R. and S. S. Awaad (2008): Response of yield attributes of some bread wheat varieties to irrigation levels and seeding rates under old land conditions. J. Agric. Sci., Mansoura Univ., 33(7): 4717-4737.

Ramburan, S., and P. L. Greenfield. 2007. The effects of chlormequat chloride and ethephon on agronomic and quality characteristics of South African irrigated wheat. S. Afr. J. plant Soil. 24(2):106-113.

Shekoofa, A., and Y. Emam. 2008. Effects of nitrogen fertilization and plant growth regulators (PGRs) on yield of wheat (Triticum aestivum L.) cv. Shiraz. J. Agric. Sci .Technol. 10:101-108.

Sinniah, U. R., S. Wahyuni, B. S. A. Syahputra, and S. Gantait. 2012. A potential retardant for lodging resistance in direct seeded rice (Oryza sativa L.). Can. J. Plant Sci. 92:13-18.

Tripathi, S. C., K. D. Sayre, J. N. Kaul, and R. S. Narang. 2004. Lodging behavior and yield potential of spring wheat (Triticum aestivum L.): effects of ethephon and genotypes. Field Crops Res. 87:207-220.

Webster JR, Jackson LF. 1993. Management practices to reduce lodging and maximize grain yield and protein content of fall-sown irrigated hard red spring wheat. Field Crops Research 33: 249-259. 
